\title{
Response of Nitrogen Metabolism in Masson Pine Needles to Elevated $\mathrm{CO}_{2}$
}

\author{
Fan $\mathrm{Wu}^{1}{ }^{1}$, Xiaobo Sun ${ }^{1}$, Xingfeng Hu ${ }^{1}$, Bingzhang Zou ${ }^{2}$, Nengqing Lin ${ }^{2}$, Jingquan Lin $^{2}$ and \\ Kongshu Ji $1, *$ (i) \\ 1 Key Laboratory of Forestry Genetics \& Biotechnology of Ministry of Education, Co-Innovation Center for \\ Sustainable Forestry in Southern China, Nanjing Forestry University, Nanjing 210037, China; \\ eiknarf@126.com \\ 2 Baisha State-Owned Forest Farm, Shanghang 364200, China \\ * Correspondence: ksji@njfu.edu.cn; Tel.: +86-025-85427308
}

Received: 6 February 2020; Accepted: 31 March 2020; Published: 1 April 2020

\begin{abstract}
To explore the response of nitrogen metabolism in Masson pine (Pinus massoniana) to high $\mathrm{CO}_{2}$ concentrations, needles from one-year-old seedlings were used as materials to detect key enzyme activities, gene expression and different forms of nitrogen metabolites after $\mathrm{CO}_{2}$ stress for different durations $(0 \mathrm{~h}, 6 \mathrm{~h}, 12 \mathrm{~h}, 24 \mathrm{~h})$. The results show that elevated $\mathrm{CO}_{2}$ affected the efficiency of nitrogen metabolism in Masson pine needles, inhibiting the expression of key genes involved in nitrogen metabolism, including glutamate synthase (GOGAT), nitrite reductase (NiR), glutamine synthase (GS), nitrate reductase (NR) and glutamate dehydrogenase (GDH), and decreasing the activities of GOGAT, NiR, and GS. The decrease in enzyme activities and gene expression caused a decrease in different forms of nitrogen metabolites, including total nitrogen, ammonium, nitrite and specific amino acids. With prolonged stress, the nitrate content increased first and then decreased. In this study, the response pattern of nitrogen metabolism to $\mathrm{CO}_{2}$ stress in Masson pine needles was described, which may aid future research on nitrogen utilization in Masson pine.
\end{abstract}

Keywords: masson pine; nitrogen metabolism; elevated $\mathrm{CO}_{2}$; stress

\section{Introduction}

With the advent of the industrial revolution, the concentration of $\mathrm{CO}_{2}$ in the atmosphere has increased as a result of human activities. According to the Global Carbon Project (GCP), the global atmospheric $\mathrm{CO}_{2}$ concentration reached $407.38 \pm 0.1 \mathrm{ppm}$ averaged over 2018, and will rise to approximately 500 ppm by the middle of this century and to 700-1260 ppm by the end of this century [1,2]. The effect of increased $\mathrm{CO}_{2}$ concentrations on the environment, especially on plants, is obvious because the rate at which plants adapt to $\mathrm{CO}_{2}$ does not parallel the rate at which the $\mathrm{CO}_{2}$ concentration increases $[3,4]$.

In terms of plant nutrients, elevated $\mathrm{CO}_{2}$ will accelerate the demands of plants for nutrients, and nitrogen is usually the limiting nutrient in plants [5,6]. The increase of $\mathrm{CO}_{2}$ concentration in the environment enhanced the photosynthetic efficiency of plants, and the absorption and reduction of nitrogen elements in plants require energy and the reducing force provided by photosynthetic carbon metabolism, and the subsequent synthesis of various amino acids also requires a light reaction to provide a carbon skeleton [7,8]. Therefore, nitrogen metabolism in plants is closely related to photosynthetic carbon metabolism.

It is well known that the nitrogen absorbed by plants during the growth process mainly comes from two types of mineral nitrogen sources, ammonium $\left(\mathrm{NH}_{4}{ }^{+}\right)$and nitrate $\left(\mathrm{NO}_{3}{ }^{-}\right)$. Studies have shown that different plants have different utilization efficiency of different forms of nitrogen under elevated 
$\mathrm{CO}_{2}$. For inorganic nitrogen, Men [9] found that the concentration of $\mathrm{NO}_{3}{ }^{-}$and $\mathrm{NH}_{4}{ }^{+}$in leaves of winter wheat (Triticum aestivum) decreased under increased $\mathrm{CO}_{2}$ conditions in an air chamber. $\mathrm{Xu}$ [10] also noted that an increase in the $\mathrm{CO}_{2}$ concentration inhibited the reduction of $\mathrm{NO}_{3}{ }^{-}$and reduced the nitrogen content in the flag leaves of winter wheat. For coniferous plants, Bassirirad et al. [11] and $\mathrm{Su}$ [12] showed that the $\mathrm{NO}_{3}{ }^{-}$concentration in Loblolly pine (Pinus taeda) and Camphor pine (Pinus sylvestris var. mongolica) increased with the enrichment of atmospheric $\mathrm{CO}_{2}$, while the $\mathrm{NH}_{4}{ }^{+}$ concentration did not change significantly, and Johnson et al. [13] suggested that $\mathrm{CO}_{2}$ stress would lead to a decrease in the concentration of $\mathrm{NH}_{4}{ }^{+}$in Ponderosa pine (Pinus ponderosa). According to previous reports, it can be seen that compared with crops, $\mathrm{NO}_{3}{ }^{-}$may be a more nitrogen source that coniferous plants tend to use under $\mathrm{CO}_{2}$ stress. In terms of amino acids, previous studies on species including rice (Oryza sativa) [14], European red pine (Pinus sylvestris) [15] and cotton (Gossypium spp) [16] indicated that elevated $\mathrm{CO}_{2}$ would lead to the increase of amino acids. For the total nitrogen, Han [17], Wang [18] and $\mathrm{Li}$ [19] proved that enrichment $\mathrm{CO}_{2}$ concentration would inhibit total nitrogen level in plants.

Regarding nitrogen assimilation, studies found that a high concentration of $\mathrm{CO}_{2}$ could increase the activity of nitrate reductase (NR) or glutamine synthase (GS) in Brassica napus [20]. However, some scholars have noted that elevated $\mathrm{CO}_{2}$ leads to decreased NR activity in wheat leaves [21]. Bauer [22] and Constable [23] confirmed that the increased $\mathrm{CO}_{2}$ would not affect the NR activity of Eastern White Pine (Pinus strobus) and Loblolly pine. This may suggest that herbs have more plasticity in function than coniferous plants under increased $\mathrm{CO}_{2}$ concentrations.

Masson pine (Pinus massoniana) is widely distributed in subtropical areas of China. Due to its tolerance to drought and barren lands, it has become the main pioneer tree species for afforestation and vegetation restoration in China [24,25]. At present, studies on nitrogen metabolism in Masson pine mainly focus on the effects of nitrogen deposition [26] and industrial pollution [27] on nitrogen distribution or the use of new technology to detect the nitrogen content in leaves [28]. However, few studies regarding nitrogen metabolism under $\mathrm{CO}_{2}$ stress have been performed. Based on the previous research progress in conifers, we speculated that, when the environmental $\mathrm{CO}_{2}$ concentration increased, the utilization efficiency of nitrogen in different forms would be different. Masson pine might be more inclined to use $\mathrm{NO}_{3}{ }^{-}$as a nitrogen source. The content of amino acids would increase, and the total nitrogen level would decrease. In terms of enzyme activity, the activity of NR would not be affected by elevated $\mathrm{CO}_{2}$, while that of other key enzymes would decrease or remained unchanged with the extension of treatment time. In addition, the response of key genes involved in the regulation of nitrogen metabolism to $\mathrm{CO}_{2}$ stress has been rarely studied. Will their expression level be consistent with changes in enzyme activity and nitrogen content in different forms? In order to confirm the above hypothesis, in this study, Masson pine was exposed to high $\mathrm{CO}_{2}$ concentrations, and the changes in nitrogen with different forms, in the corresponding regulatory enzymes activities and genes expression level were detected, to fill the gap in this field, reveal the influence of $\mathrm{CO}_{2}$ stress on nitrogen transport and redistribution in Masson pine and to provide a scientific basis for fertilizer management and selection strategies in response to climate change.

\section{Materials and Methods}

\subsection{Plant Materials and Experimental Design}

One-year-old Masson pine seedlings, obtained from the seed orchard of the Baisha state-owned forest farm, Shanghang, Fujian Province, China $\left(25^{\circ} 15^{\prime} \mathrm{N}, 116^{\circ} 62^{\prime} \mathrm{E}\right)$, were used in this study. Three individuals of the same clones with similar heights and uniform vigorous growth were chosen as the materials. After 10 days of recovery, the seedlings were subsequently moved into a growth chamber. The growth conditions were $10 \mathrm{~h}$ light/ $14 \mathrm{~h}$ dark cycles at $25^{\circ} \mathrm{C}$ in the chamber. Air containing approximately 800-1000 ppm $\mathrm{CO}_{2}$ (approximately two times the ambient $\mathrm{CO}_{2}$ concentration) was aerated into the growth chamber constantly for at least $24 \mathrm{~h}$. The $\mathrm{CO}_{2}$ concentration in the chamber was monitored by an infrared $\mathrm{CO}_{2}$ analysis reader (SenseAir, Delsbo, Sweden). Three biological replicates 
for each treatment were sampled at $0 \mathrm{~h}$ (control check group, CK), $6 \mathrm{~h}, 12 \mathrm{~h}, 24 \mathrm{~h}$, and every sample was divided into three parts, two of which were immediately stored in liquid nitrogen for RNA extraction and nitrogen metabolite analysis, and the other one was used for related enzyme activity detection.

\subsection{Determination of the Content of Different Forms of Nitrogen}

Samples with different treatment times were dried at $80{ }^{\circ} \mathrm{C}$ to a constant weight. Then, $0.2 \mathrm{~g}$ of sample was weighed, and the total nitrogen was determined by the Kjeldahl method [29].

Samples $(1 \mathrm{~g})$ treated with different stress treatment times were cut into pieces, ground with a small amount of double distilled water $\left(\mathrm{ddH}_{2} \mathrm{O}\right)$ in a mortar, transferred into a dry triangular flask, supplemented with $\mathrm{ddH}_{2} \mathrm{O}$ to a final volume of $20 \mathrm{~mL}$, oscillated and finally allowed to rest for clarification. For $\mathrm{NH}_{4}{ }^{+}$determination, $5 \mathrm{~mL}$ of supernatant was extracted and placed in a $25 \mathrm{~mL}$ volumetric flask, and then $2.5 \mathrm{~mL}$ of reaction buffer $\mathrm{A}(0.1 \mathrm{M}$ phenol, $0.3 \mathrm{mM}$ sodium nitroprusside $\left(\mathrm{Na}_{2} \mathrm{Fe}(\mathrm{CN})_{5} \mathrm{NO} \cdot 2 \mathrm{H}_{2} \mathrm{O}\right)$, stored in a brown bottle at $\left.4{ }^{\circ} \mathrm{C}\right), 2.5 \mathrm{~mL}$ reaction buffer $\mathrm{B}(0.25 \mathrm{M} \mathrm{NaOH}$, $0.05 \mathrm{M} \mathrm{Na}_{2} \mathrm{HPO}_{4}, 0.2 \mathrm{M} \mathrm{Na}_{3} \mathrm{PO}_{4}, 7 \mathrm{mM} \mathrm{NaClO}$, stored in a brown bottle at $4{ }^{\circ} \mathrm{C}$ ) and $0.5 \mathrm{~mL}$ masking agent (1.4 M Seignette salt $\left(\mathrm{C}_{4} \mathrm{H}_{12} \mathrm{KNaO}_{10}\right), 0.3 \mathrm{M}$ EDTA-2Na, $0.05 \mathrm{M} \mathrm{NaOH}$ ) were added. Then, the mixed solution was adjusted to $25 \mathrm{~mL}$ with ddH2O and measured at $625 \mathrm{~nm}$. For $\mathrm{NO}_{3}{ }^{-}$determination, $2 \mathrm{~mL}$ supernatant was extracted, and then, $18 \mathrm{~mL}$ acetic acid and $0.4 \mathrm{~g}$ mixed powder $\left(\mathrm{BaSO}_{4}\right.$ : $\alpha$-naphthylamine: zinc powder: p-aminobenzene sulfonic acid: MnSO4: citric acid = 100:2:2:4:10:75) were added. Then, the mixture was vigorously shaken for $1 \mathrm{~min}$ and centrifuged at $4000 \mathrm{rpm}$ for $5 \mathrm{~min}$, and the supernatant was measured at $520 \mathrm{~nm}$. For $\mathrm{NO}_{2}{ }^{-}, 5 \mathrm{~mL}$ supernatant was extracted and mixed with $0.2 \mathrm{~mL}$ chromogenic agent $\left(0.58 \mathrm{M}\right.$ sulfanilamide $\left(\mathrm{C}_{6} \mathrm{H}_{8} \mathrm{~N}_{2} \mathrm{O}_{2} \mathrm{~S}\right), 15 \mathrm{mM}$ hydrochloric acid $\mathrm{N}$-(1-naphthyl) ethylenediamine $\left.\left(\mathrm{C}_{12} \mathrm{H}_{14} \mathrm{~N}_{2} \cdot 2 \mathrm{HCl}\right), 2 \mathrm{~N} \mathrm{H}_{3} \mathrm{PO}_{4}\right)$. Then, the mixed solution was adjusted to $25 \mathrm{~mL}$ with $\mathrm{ddH}_{2} \mathrm{O}$, allowed to stand for $1 \mathrm{~h}$ and measured at $543 \mathrm{~nm}$ [30].

\subsection{Free Amino Acid Detection}

A total of $20 \mathrm{mg}$ of sample was weighed in a $2 \mathrm{~mL}$ microcentrifuge tube. After the addition of $400 \mu \mathrm{L}$ of extraction buffer (acetonitrile: methanol: water, 2:2:1, containing adonitol $1 \mu \mathrm{g} \cdot \mathrm{mL}^{-1}$ as the internal standard), the samples were vortexed for $30 \mathrm{~s}$, homogenized at $35 \mathrm{~Hz}$ for $4 \mathrm{~min}$, and sonicated for $5 \mathrm{~min}$ in an ice-water bath. The homogenate and sonicate cycle was repeated 3 times, followed by incubation at $-20^{\circ} \mathrm{C}$ for $1 \mathrm{~h}$ and centrifugation at $12000 \mathrm{rpm}$ and $4{ }^{\circ} \mathrm{C}$ for $15 \mathrm{~min}$. The resulting supernatants were transferred to LC-MS vials and stored at $-80^{\circ} \mathrm{C}$. The quality control sample was prepared by mixing an equal aliquot of the supernatants from all of the samples.

LC-MS/MS analyses were performed using a UHPLC system (1290, Agilent Technologies, Santa Clara, CA, USA) with a UPLC HSS T3 column $(2.1 \mathrm{~mm} \times 100 \mathrm{~mm}, 1.8 \mu \mathrm{m}$, Waters, Milford, MA, USA) coupled to Q Exactive (Orbitrap MS, Thermo, Waltham, MA, USA). Mobile phase A was $0.1 \%$ formic acid in water for the positive mode, and $5 \mathrm{mmol} \cdot \mathrm{L}^{-1}$ ammonium acetate in water for the negative mode. Mobile phase $B$ was acetonitrile. The elution gradient was set as follows: 0 min, $1 \% \mathrm{~B} ; 1 \mathrm{~min}$, $1 \% \mathrm{~B} ; 8 \mathrm{~min}, 99 \% \mathrm{~B} ; 10 \mathrm{~min}, 99 \% \mathrm{~B} ; 10.1 \mathrm{~min}, 1 \% \mathrm{~B}$; and $12 \mathrm{~min}, 1 \% \mathrm{~B}$. The flow rate was $0.5 \mathrm{~mL} \cdot \mathrm{min}^{-1}$. The injection volume was $2 \mu \mathrm{L}$. The QE mass spectrometer was used for its ability to acquire MS/MS spectra on an information-dependent basis (IDA) during an LC/MS experiment. In this mode, the acquisition software Xcalibur version 4.0.27 (Thermo, Waltham, MA, USA) continuously evaluates the full-scan survey MS data as it collects and triggers the acquisition of MS/MS spectra depending on preselected criteria. Electron spray ionization (ESI) source conditions were set as follows: The sheath gas flow rate was $45 \mathrm{Arb}$, Aux gas flow rate was $15 \mathrm{Arb}$, capillary temperature was $400{ }^{\circ} \mathrm{C}$, full MS resolution was 70,000, MS/MS resolution was 17,500, collision energy was 20/40/60 eV in the NCE model, and the spray voltage was $4.0 \mathrm{kV}$ (positive) or $-3.6 \mathrm{kV}$ (negative).

\subsection{Nitrogen Metabolism Enzyme Activities}

The activity of glutamine synthase (GS) was determined by homogenizing the fresh sample (g) with the extraction buffer $\left(0.05 \mathrm{M}\right.$ Tris- $\mathrm{HCl}, 2 \mathrm{mM} \mathrm{Mg}{ }^{2+}, 2 \mathrm{mM}$ dithiothreitol (DTT), $0.4 \mathrm{M}$ saccharose, 
$\mathrm{pH}$ 8.0) at a 1:10 ratio in an ice-water bath and centrifuging for $10 \mathrm{~min}$ at $4000 \mathrm{rpm}$. Then, $400 \mu \mathrm{L}$ supernatant was mixed with $175 \mu \mathrm{L}$ reaction mixture $\left(0.1 \mathrm{mM}\right.$ Tris- $\mathrm{HCl}, 80 \mathrm{mM} \mathrm{Mg}{ }^{2+}, 20 \mathrm{mM}$ sodium 2-aminopentanedioate $\left(\mathrm{C}_{5} \mathrm{H}_{8} \mathrm{NNaO}_{4}\right), 20 \mathrm{mM}$ cysteine, $2 \mathrm{mM}$ EDTA, $80 \mathrm{mM}$ hydroxylamine hydrochloride $\left.\left(\mathrm{NH}_{3} \mathrm{OHCl}\right), \mathrm{pH} 7.4\right)$, and reacted at $25{ }^{\circ} \mathrm{C}$ for $30 \mathrm{~min}$. Then, $250 \mu \mathrm{L}$ chromogenic agent $\left(0.2 \mathrm{M}\right.$ trichloroacetic acid (TCA), $0.37 \mathrm{M} \mathrm{FeCl}_{3}, 0.6 \mathrm{M} \mathrm{HCl}$ ) was added. Samples were centrifuged at $4000 \mathrm{rpm}$ for $5 \mathrm{~min}$ and the absorbance of $\gamma$-glutamylmonohydroxamate $(\gamma$-GHM) in the supernatant was measured at $540 \mathrm{~nm}$. The activity determination of nitrate reductase (NR) was first mixed and homogenized $0.1 \mathrm{~g}$ fresh sample with $1 \mathrm{~mL}, 0.1 \mathrm{M}$ phosphate buffer in ice-water bath, and the supernatant was obtained after centrifuging for $10 \mathrm{~min}$ at $4000 \mathrm{rpm}$. The reaction was incubated for $30 \mathrm{~min}$ at $25^{\circ} \mathrm{C}$ after the addition of $100 \mu \mathrm{L}$ of enzyme extract to $500 \mu \mathrm{L}$ of reaction buffer $(20 \mathrm{mM}$ $\left.\mathrm{NADH}, 20 \mathrm{mM} \mathrm{KNO}{ }_{3}\right)$. The $500 \mu \mathrm{L}$ chromogenic agent $\left(60 \mathrm{mM}\right.$ sulfanilic acid $\left(\mathrm{C}_{6} \mathrm{H}_{7} \mathrm{NO}_{3} \mathrm{~S}\right), 3 \mathrm{M}$ $\mathrm{HCl}, 1.4 \mathrm{mM} \alpha$-naphthylamine) was then added and the samples were measured colorimetrically at $540 \mathrm{~nm}$ after incubating for $20 \mathrm{~min}$ at $25^{\circ} \mathrm{C}$. The activities of glutamate dehydrogenase (GDH) and glutamate synthase (GOGAT) were determined by the decline rate of NADH absorbance at $340 \mathrm{~nm}$ in a reaction consisting of $900 \mu \mathrm{L}$ protein extract $(0.1 \mathrm{~g}$ fresh sample added into $1 \mathrm{~mL}, 0.1 \mathrm{M}$ Tris- $\mathrm{HCl}$, $\mathrm{pH}$ 8.0, homogenizing in ice-water bath and then centrifuging for $10 \mathrm{~min}$ at $4000 \mathrm{rpm}$ ) and $100 \mu \mathrm{L}$ of reaction buffer for GDH (0.1 M Tris- $\mathrm{HCl}, 1.5 \mathrm{M} \mathrm{NH}_{4} \mathrm{Cl}, 0.25 \mathrm{M} \alpha$-ketoglutarate, $7.5 \mathrm{mM}$ NADH, pH 8.0) or for GOGAT (0.1 M Tris-HCl, $10 \mathrm{mM}$ dithiothreitol (DTT), 0.25 M $\alpha$-ketoglutarate, 7.5 mM NADH, $\mathrm{pH}$ 8.6). For nitrite reductase (NiR) activity, the enzyme extract was obtained by homogenizing $0.1 \mathrm{~g}$ fresh sample and $1 \mathrm{~mL}$ extraction buffer ( $50 \mathrm{mM}$ phosphate buffer, $1 \mathrm{mM}$ EDTA, $3 \mathrm{mM}$ cysteine, $\mathrm{pH}$ 7.5). Then, the reaction was incubated for $60 \mathrm{~min}$ at $25^{\circ} \mathrm{C}$ after mixing $100 \mu \mathrm{L}$ enzyme extract with $400 \mu \mathrm{L}$ reaction buffer ( $50 \mathrm{mM}$ Tris- $\mathrm{HCl}, 0.5 \mathrm{mM} \mathrm{KNO}_{2}, 1 \mathrm{mM}$ methylviologen, $\mathrm{pH} 7.5$ ) and $120 \mu \mathrm{L} 0.12 \mathrm{M}$ $\mathrm{Na}_{2} \mathrm{~S}_{2} \mathrm{O}_{4}$. The reaction was stopped by adding $200 \mu \mathrm{L}, 1 \mathrm{M}$ zinc acetate. Then, $350 \mu \mathrm{L}$ supernatant was added with $700 \mu \mathrm{L}$ chromogenic agent ( $60 \mathrm{mM}$ sulfanilic acid, $3 \mathrm{M} \mathrm{HCl}, 1.4 \mathrm{mM} \alpha$-naphthylamine), and measured under $540 \mathrm{~nm}$.

\subsection{RNA Extraction, Complementary DNA (cDNA) Synthesis and Quantitative Real-Time PCR (qRT-PCR)}

Total RNA from seedlings under four treatment conditions $(0 \mathrm{~h}, 6 \mathrm{~h}, 12 \mathrm{~h}$ and $24 \mathrm{~h})$ was extracted with three biological replicates for each treatment using the Plant RNA Isolation kit (Tiangen Biotech, Beijing, China). Then, first-strand cDNA was synthesized with FastKing gDNA Dispelling RT SuperMix (item number: KR118-02, Tiangen Biotech, Beijing, China) according to the manufacturer's instructions. For qRT-PCR, the mixtures consisted of $10 \mu \mathrm{L}$ of $2 \times$ ChamQTM Universal SYBR ${ }^{\circledR}$ qPCR Master Mix (item number: Q711-02, Vazyme Biotech, Nanjing, China), $0.4 \mu \mathrm{L}$ of forward primer and reverse primer, $2 \mu \mathrm{L}$ of cDNA, and $7.2 \mu \mathrm{L}$ of $\mathrm{ddH}_{2} \mathrm{O}$. The qRT-PCR program was set up in three stages: (1) $95^{\circ} \mathrm{C}$ for $30 \mathrm{~s}$ (preincubation), (2) $95^{\circ} \mathrm{C}$ for $10 \mathrm{~s}, 60^{\circ} \mathrm{C}$ for $30 \mathrm{~s}, 72^{\circ} \mathrm{C}$ for $30 \mathrm{~s}$, repeated 40 times (amplification), (3) $95^{\circ} \mathrm{C}$ for $15 \mathrm{~s}, 60^{\circ} \mathrm{C}$ for $1 \mathrm{~min}$ and $95^{\circ} \mathrm{C}$ for $15 \mathrm{~s}$ (melting curves). The qRT-PCR quality was estimated based on the melting curves. Alpha-tubulin (TUA) was used as the internal control [31]. The gene-specific primers employed are shown in Table 1. Three independent biological replicates and three technical replicates for each biological replicate were run. Quantification was achieved using comparative cycle threshold $(\mathrm{Ct})$ values, and gene expression levels were calculated using the $2^{-\Delta \Delta \mathrm{Ct}}$ method [31]. 
Table 1. Primers used in this study.

\begin{tabular}{|c|c|c|}
\hline Primer & & Sequence $\left(5^{\prime} \rightarrow 3^{\prime}\right)$ \\
\hline qGS_F & Forward & GACTTCTGAACAGCAAAATGGTC \\
\hline qGS_R & Reverse & GCAATCAGTTTAGATGGGCATAG \\
\hline qNR_F & Forward & AACTGACAGCACTCTGAAACTCC \\
\hline qNR_R & Reverse & AATATACATGTGGCCGTGAGAAG \\
\hline qGDH_F & Forward & GGTCATTCTCCTGCAGTTGTTAC \\
\hline qGDH_R & Reverse & ATGTTCAGCTAACAAGGCTTCTG \\
\hline qNiR_F & Forward & GAAGACGGGAGACATAGAGGACT \\
\hline qNiR_R & Reverse & TAGATATAATCCGGGTCCACCTT \\
\hline qGOGAT_F & Forward & CAAATTCACTGTTGTGCAGAGAG \\
\hline qGOGAT_R & Reverse & AACAGCAACAGCAGCTACTTCTC \\
\hline
\end{tabular}

\subsection{Statistical Analysis}

The significance was determined by t-test using SPSS version 22.0 statistical software (IBM, New York, NY, USA) $(p<0.05)$. Differences in the effects of $\mathrm{CO}_{2}$ on various treatments were determined by one-way ANOVA with Duncan's new multiple tests. The raw data of metabolite detection were converted into a common format, and adducts were achieved using XCMS online [32] (http://metlin.scripps.edu/xcms/), which provides a complete metabolomics workflow, including feature detection, retention time correction, alignment, annotation and analysis [32]. The ion strength of each detection peak was determined by combining the retention time and mass-to-charge ratio $(\mathrm{m} / \mathrm{z})$ values. The peak was detected, and the metabolite was obtained by the quartile interval denoising method; the missing value of the original data was obtained using half of the minimum value [33].

\section{Results}

\subsection{Changes in Different $\mathrm{N}$ Forms under $\mathrm{CO}_{2}$ Stress}

As shown in Figure 1, different forms of nitrogen have different expression trends under $\mathrm{CO}_{2}$ stress. Among them, there was no significant difference in the total nitrogen content in Masson pine needles after $6 \mathrm{~h}$ of treatment compared with $0 \mathrm{~h}$ of treatment. When treated for $12 \mathrm{~h}$, the content decreased significantly and maintained a low level until $24 \mathrm{~h}$ (Figure 1A). The $\mathrm{NO}_{3}{ }^{-}$content first increased with increasing treatment time, peaked at $6 \mathrm{~h}$, and then continued to decline. The content was lower at $24 \mathrm{~h}$ than at $0 \mathrm{~h}$ (Figure $1 \mathrm{~B}$ ). The $\mathrm{NO}_{2}{ }^{-}$content decreased rapidly in the early stage of treatment $\left(6 \mathrm{~h}\right.$ ) and remained at a low level (Figure 1C), while $\mathrm{NH}_{4}{ }^{+}$showed a trend of continuous decrease (Figure 1D). In general, with increasing $\mathrm{CO}_{2}$ stress treatments, different forms of nitrogen showed a downward trend.

\subsection{Free Amino Acids}

The changes in the contents of twenty common free amino acids under $\mathrm{CO}_{2}$ stress are shown in Table 2. The contents of different amino acids in the elevated $\mathrm{CO}_{2}$ environment were different. Among them, the contents of asparagine, histidine, arginine and tryptophan increased with increasing stress time and reached a maximum value at $24 \mathrm{~h}$, while the content of amino acids such as glutamate, glutamine, proline and valine decreased with increasing treatment time; the difference between the different treatment times reached a significant level $(p<0.05)$. However, the change in concentration of aspartate, glycine, cysteine, phenylalanine, lysine and tyrosine showed no significant difference under $\mathrm{CO}_{2}$ stress. The total amount of amino acids did not differ significantly at $0 \mathrm{~h}, 6 \mathrm{~h}$ and $12 \mathrm{~h}$ but increased significantly at $24 \mathrm{~h}$ (Table 2). In general, the amount of amino acids increased with increasing stress time. 

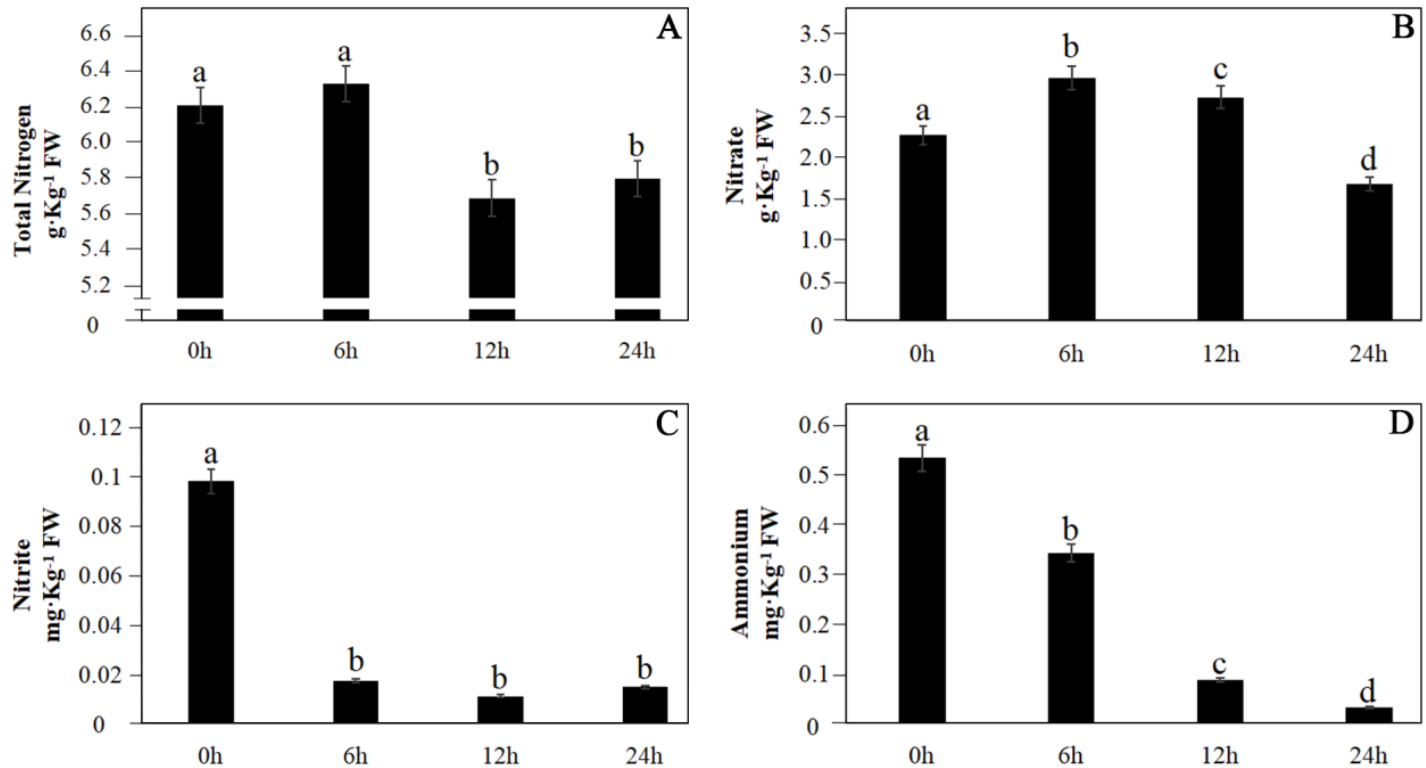

Figure 1. Effects of elevated $\mathrm{CO}_{2}$ on different nitrogen forms. (A) Total nitrogen, (B) nitrate, (C) nitrite, (D) ammonium. Significant differences $(p<0.05)$ are indicated with lowercase letters. FW, fresh weight.

Table 2. Effect of elevated $\mathrm{CO}_{2}$ on free amino acids.

\begin{tabular}{ccccc}
\hline & $\mathbf{0 ~ h}$ & $\mathbf{6 h}$ & $\mathbf{1 2} \mathbf{h}$ & $\mathbf{2 4} \mathbf{h}$ \\
\hline Aspartate & $0.030 \pm 0.002 \mathrm{a}$ & $0.031 \pm 0.052 \mathrm{a}$ & $0.010 \pm 0.052 \mathrm{a}$ & $0.007 \pm 0.001 \mathrm{a}$ \\
Serine & $0.357 \pm 0.124 \mathrm{a}$ & $0.368 \pm 0.156 \mathrm{a}$ & $0.199 \pm 0.074 \mathrm{~b}$ & $0.422 \pm 0.084 \mathrm{a}$ \\
Threonine & $0.366 \pm 0.075 \mathrm{~b}$ & $0.490 \pm 0.217 \mathrm{~b}$ & $0.563 \pm 0.200 \mathrm{~b}$ & $1.111 \pm 0.419 \mathrm{a}$ \\
Glutamate & $4.086 \pm 0.657 \mathrm{a}$ & $3.387 \pm 0.474 \mathrm{ab}$ & $3.396 \pm 0.860 \mathrm{ab}$ & $2.555 \pm 0.647 \mathrm{~b}$ \\
Glycine & $0.027 \pm 0.006 \mathrm{a}$ & $0.026 \pm 0.005 \mathrm{a}$ & $0.031 \pm 0.010 \mathrm{a}$ & $0.029 \pm 0.005 \mathrm{a}$ \\
Alanine & $0.116 \pm 0.022 \mathrm{~b}$ & $0.267 \pm 0.083 \mathrm{a}$ & $0.232 \pm 0.073 \mathrm{a}$ & $0.275 \pm 0.062 \mathrm{a}$ \\
Cysteine & $0.010 \pm 0.006 \mathrm{a}$ & $0.008 \pm 0.002 \mathrm{a}$ & $0.010 \pm 0.007 \mathrm{a}$ & $0.011 \pm 0.006 \mathrm{a}$ \\
Valine & $0.592 \pm 0.284 \mathrm{a}$ & $0.34 \pm 0.128 \mathrm{~b}$ & $0.215 \pm 0.129 \mathrm{~b}$ & $0.243 \pm 0.097 \mathrm{~b}$ \\
Methionine & $0.048 \pm 0.021 \mathrm{a}$ & $0.020 \pm 0.007 \mathrm{~b}$ & $0.013 \pm 0.001 \mathrm{~b}$ & $0.013 \pm 0.004 \mathrm{~b}$ \\
Isoleucine & $0.002 \pm 0.001 \mathrm{a}$ & $0.001 \pm 0.001 \mathrm{~b}$ & $0.002 \pm 0.001 \mathrm{ab}$ & $0.001 \pm 0.001 \mathrm{~b}$ \\
Phenylalanine & $0.299 \pm 0.061 \mathrm{a}$ & $0.288 \pm 0.055 \mathrm{a}$ & $0.285 \pm 0.167 \mathrm{a}$ & $0.359 \pm 0.162 \mathrm{a}$ \\
Lysine & $0.500 \pm 0.920 \mathrm{a}$ & $0.556 \pm 0.958 \mathrm{a}$ & $0.492 \pm 0.209 \mathrm{a}$ & $0.517 \pm 0.384 \mathrm{a}$ \\
Histidine & $0.300 \pm 0.084 \mathrm{~b}$ & $0.713 \pm 0.528 \mathrm{ab}$ & $0.622 \pm 0.726 \mathrm{ab}$ & $1.271 \pm 0.994 \mathrm{a}$ \\
Arginine & $1.748 \pm 1.687 \mathrm{~b}$ & $4.616 \pm 3.912 \mathrm{ab}$ & $3.892 \pm 5.721 \mathrm{ab}$ & $7.702 \pm 4.922 \mathrm{a}$ \\
Glutamine & $5.793 \pm 3.521 \mathrm{a}$ & $3.734 \pm 2.220 \mathrm{ab}$ & $3.125 \pm 1.090 \mathrm{ab}$ & $1.895 \pm 1.039 \mathrm{~b}$ \\
Leucine & $0.873 \pm 0.186 \mathrm{~b}$ & $0.516 \pm 0.144 \mathrm{c}$ & $0.72 \pm 0.173 \mathrm{bc}$ & $1.327 \pm 0.298 \mathrm{a}$ \\
Tyrosine & $0.276 \pm 0.071 \mathrm{a}$ & $0.206 \pm 0.096 \mathrm{a}$ & $0.236 \pm 0.090 \mathrm{a}$ & $0.289 \pm 0.113 \mathrm{a}$ \\
Tryptophan & $1.414 \pm 0.815 \mathrm{~b}$ & $1.794 \pm 0.332 \mathrm{ab}$ & $2.362 \pm 0.909 \mathrm{a}$ & $2.650 \pm 0.537 \mathrm{a}$ \\
Proline & $0.648 \pm 0.202 \mathrm{a}$ & $0.493 \pm 0.151 \mathrm{ab}$ & $0.483 \pm 0.208 \mathrm{ab}$ & $0.310 \pm 0.071 \mathrm{~b}$ \\
Asparagine & $0.114 \pm 0.056 \mathrm{~b}$ & $0.214 \pm 0.091 \mathrm{~b}$ & $0.426 \pm 0.336 \mathrm{~b}$ & $0.933 \pm 0.733 \mathrm{a}$ \\
Total & $17.572 \pm 1.490 \mathrm{~b}$ & $18.068 \pm 1.370 \mathrm{~b}$ & $17.314 \pm 1.239 \mathrm{~b}$ & $21.230 \pm 2.944 \mathrm{a}$ \\
\hline
\end{tabular}

Significant differences $(p<0.05)$ are indicated by lowercase letters.

\subsection{Enzyme Activities and Gene Expression}

An increase in the $\mathrm{CO}_{2}$ concentration resulted in increased GDH (Figure 2A) and NR (Figure 2C) activities, among which GDH was significantly different between different treatments, while NR activity was only slightly upregulated after $6 \mathrm{~h}$, and no significant difference existed between treatment groups. Other enzyme activities decreased with increasing stress time (Figure 2E,G,I), among which GS was the most obvious. 

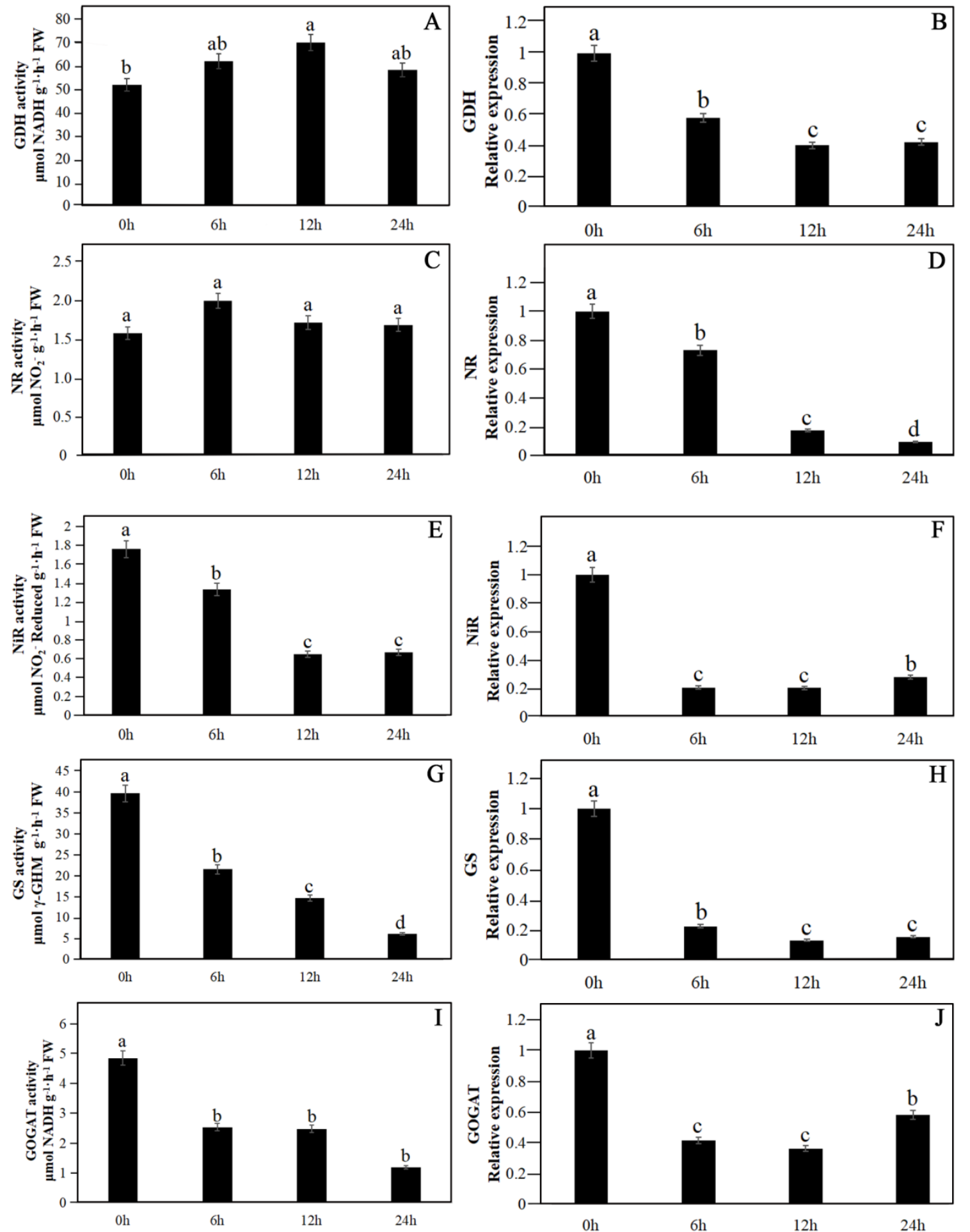

Figure 2. Response of nitrogen metabolic enzyme activities and gene expression changes in Masson pine needles at different times under $\mathrm{CO}_{2}$ stress. Significant differences $(p<0.05)$ are indicated by lowercase letters. (A,B) Glutamate dehydrogenase (GDH), (C,D) nitrate reductase (NR), (E,F) nitrite reductase (NiR), (G,H) glutamine synthetase (GS), and (I,J) glutamate synthase (GOGAT). FW, fresh weight; $\gamma$-GHM, $\gamma$-glutamyl hydroxamate; NADH, nicotinamide adenine dinucleotide.

The expression patterns of key genes involved in nitrogen metabolism in a high $\mathrm{CO}_{2}$ environment is shown in Figure 2. Among them, the expression of NR continued to decrease, reaching the lowest value at $24 \mathrm{~h}$, and there was a significant difference between the expression levels corresponding to each treatment time node (Figure 2D). The expression trends of GDH and GS were similar. Their expression 
levels no longer changed significantly after $12 \mathrm{~h}$ of stress treatment (Figure 2B,H). Interestingly, the expression levels of NiR and GOGAT decreased first, and there were no differences at $6 \mathrm{~h}$ and $12 \mathrm{~h}$. However, after $24 \mathrm{~h}$, the expression levels increased again but did not return to the untreated level $(0 \mathrm{~h})$. The expression levels at $24 \mathrm{~h}$ increased significantly compared with those at $6 \mathrm{~h}$ and $12 \mathrm{~h}$ (Figure 2F,J). Overall, the expression of all genes showed a downregulated trend with increased treatment time.

\section{Discussion}

\subsection{Effects of Elevated $\mathrm{CO}_{2}$ on Different Nitrogen Forms}

Plants showed great flexibility and differences in the uptake and metabolism of different nitrogen forms under stress [34]. The results of this experiment show that with an increasing $\mathrm{CO}_{2}$ concentration, the $\mathrm{NO}_{3}{ }^{-}$content in Masson pine needles increased slightly in the early stage (0-12 h) and later (after $24 \mathrm{~h}$ ) was lower than that in the control $(0 \mathrm{~h})$. Previous studies have found that when the concentration of $\mathrm{CO}_{2}$ in the plasma membrane increases, the conversion efficiency of $\mathrm{CO}_{2}$ to $\mathrm{HCO}_{3}{ }^{-}$also increased at the same time, resulting in the difference between the concentration of $\mathrm{HCO}_{3}{ }^{-}$inside and outside the plasma membrane. The absorption of $\mathrm{NO}_{3}{ }^{-}$is coupled with the transmembrane exchange of $\mathrm{HCO}_{3}{ }^{-}$. Therefore, with the outflow of $\mathrm{HCO}_{3}{ }^{-}$in the plasma membrane, increasing $\mathrm{NO}_{3}{ }^{-}$will enter the plasma membrane, leading to an increase in its content $[35,36]$. On the other hand, the contents of $\mathrm{NO}_{2}{ }^{-}$and $\mathrm{NH}_{4}{ }^{+}$decreased continuously with increasing stress time, reaching the lowest value at $24 \mathrm{~h}$ (Figure 1C,D). Thornton [37] noted that plants had feedback regulation on the absorption and metabolism of $\mathrm{NH}_{4}{ }^{+}, \mathrm{NO}_{2}{ }^{-}$and $\mathrm{NO}_{3}{ }^{-}$; therefore, an increase in the $\mathrm{NO}_{3}{ }^{-}$content may cause a decrease in the other two forms of nitrogen. Furthermore, Ma [38] noted that an increase in the amino acid content would also inhibit the absorption and metabolism of inorganic nitrogen by plants. In general, the content of amino acids increased with increasing stress time and reached a maximum value at $24 \mathrm{~h}$, particularly for threonine, arginine and tryptophan (Table 2). Therefore, the increase in the amino acid content may also be another explanation for the decline in the $\mathrm{NH}_{4}{ }^{+}, \mathrm{NO}_{2}{ }^{-}$, and $\mathrm{NO}_{3}{ }^{-}$contents after $24 \mathrm{~h}$. In terms of the total nitrogen content, there was no significant change within $6 \mathrm{~h}$; however, it began to decrease after $12 \mathrm{~h}$ and was lower at $12 \mathrm{~h}$ than at $0 \mathrm{~h}$, eventually reaching a significant level. Studies have shown that an increase in the $\mathrm{CO}_{2}$ concentration will reduce the total nitrogen concentration in plants $[39,40]$, but the reasons vary in different reports. When Li [19] studied the change in the total nitrogen content in tea leaves under $\mathrm{CO}_{2}$ and high temperature stress, he found that the decrease in the free amino acid and caffeine contents was the main reason for the decrease in the total nitrogen content. Weigel [41] believed that the decrease in total nitrogen was related to the increase in the carbohydrate content in plants. The results of our experiment show that the main reason for the decrease in the total nitrogen in Masson pine needles may be the decrease in the inorganic nitrogen content. Perhaps because of the different responses of different species to elevated $\mathrm{CO}_{2}$ or the application of other stress treatments at the same time, there were differences in the reasons for the decrease in the total nitrogen content in leaves in different reports.

\subsection{Enzyme Activities and Gene Expression Response to $\mathrm{CO}_{2}$ Stress}

According to the results of this experiment, NiR and GS activities decreased with increasing treatment time under $\mathrm{CO}_{2}$ stress (Figure 2E,G). This would lead to a decrease in the contents of $\mathrm{NH}_{4}{ }^{+}$ and glutamine, the products catalyzed by the two reactions. This inference was confirmed by the corresponding experimental results (Figure 1D, Table 2). When Li [42] studied the response of nitrogen metabolism in cucumber (Cucumis sativus) under $\mathrm{CO}_{2}$ stress, the activity of $\mathrm{NiR}$ changed in a way that contrasts the changes in $\mathrm{NiR}$ activity in our study. It is possible that $\mathrm{Li}$ applied $\mathrm{NaCl}$ stress at the same time, resulting in inconsistent results. The response of GS was consistent with that reported in other species [43]. In addition, the activity of GOGAT showed a decreasing trend (Figure 2I), while GDH correspondingly increased at the same time (Figure 2A). GOGAT and GDH are two key enzymes involved in the transformation of $\alpha$-ketoglutaric acid into glutamate in plant cells. GOGAT uses 
glutamine as the nitrogen source for glutamate synthesis, while GDH uses $\mathrm{NH}_{4}{ }^{+}$[44]. Our results showed that under $\mathrm{CO}_{2}$ stress, the metabolic pathway of GOGAT was inhibited, and Masson pine synthesized glutamate mainly through the GDH pathway. Therefore, increasing $\mathrm{NH}_{4}{ }^{+}$was consumed, leading to a decrease in its content (Figure 1D). On the other hand, there was no significant difference in the NR activity in each treatment, indicating that $\mathrm{NR}$ was not affected by $\mathrm{CO}_{2}$ stress (Figure 2C). Interestingly, the NR response patterns were significantly different from those previously reported. The results of Torralbo et al. [45] were consistent with this experiment. Perez-Lopez et al. [46] noted that increasing the $\mathrm{CO}_{2}$ concentration alone did not affect the activity of actual nitrate reductase (NRact). However, when $\mathrm{NaCl}$ stress was applied at the same time, the NRact activity increased. Zaghdoud et al. [47] showed the same NR activity response to $\mathrm{CO}_{2}$ and drought stress as Usue. Anabel et al. [48] confirmed that NR activity showed a continuous increasing trend under drought and $\mathrm{CO}_{2}$ stresses. These differences in results may be due to the differences in the materials and experimental designs used. Further experimental verification of the mechanism of NR activity under $\mathrm{CO}_{2}$ stress is needed.

At the gene level, the results show that $\mathrm{CO}_{2}$ enrichment comprehensively inhibited the expression of key genes involved in nitrogen metabolism (Figure 2B,D,F,H,G). This highlighted the phenomenon that $\mathrm{CO}_{2}$ stress could damage nitrogen assimilation in Masson pine, which might be related to the carbon pool and source imbalance in needles [45]. Notably, when Vicente [49] studied the response mode of durum wheat nitrogen metabolism genes under the stress of nitrogen supply, temperature and $\mathrm{CO}_{2}$, he found that elevated $\mathrm{CO}_{2}$, atmospheric temperature and low $\mathrm{N}$ supply could induce the expression of GS and Fd-GOGAT with an upregulated trend, while the expression of other genes was inhibited. We speculated that the cross-talk mechanism between different stresses was the reason for this finding [50]. On the other hand, when we analyzed the correlation between genes and enzyme activities, we found that the enzyme activity and gene expression levels of NiR, GS and GOGAT showed a similar trend. They all decreased with the extension of treatment time. Interestingly, while the enzyme activity of NR remained unchanged, the gene expression decreased gradually (Figure 2C,D). In addition, GDH gene expression was gradually downregulated, while its enzyme activity increased (Figure 2A,B). The reason for the desynchronization of the NR gene and enzyme activity may be its complex stress mechanism. The reason for the difference between the gene expression and enzyme activity of GDH was speculated to be due to the presence of two types of GDH enzymes (NADH-GDH and NADPH-GDH) in plant cells [44], and the obtained enzyme activity data might contain both expression amounts, leading to an increase in the final amount.

Noteworthily, the previous studies have shown that the nitrogen fixation ability and the changes of nitrogen in plants are also affected by soil fertility [51,52], soil microorganisms $[53,54]$ or metal elements [55]. We studied the change of elevated $\mathrm{CO}_{2}$ content as the main factor but did not verify or discuss the influence of other factors on nitrogen metabolism of Masson pine under the same condition. With the increase of atmospheric $\mathrm{CO}_{2}$ concentration, are there other factors that can affect nitrogen in Masson pine? What are their influence patterns and mechanisms? Is there any cross-talk between these factors? Perhaps all this needs to be proved by further research.

\section{Conclusions}

This study attempted to explore the response patterns of nitrogen metabolism in Masson pine needles to high $\mathrm{CO}_{2}$ stress. The experimental results showed that elevated $\mathrm{CO}_{2}$ leaded to an increase in the concentration of $\mathrm{NO}_{3}{ }^{-}$and amino acids and a decrease in the total nitrogen, inhibiting the key genes expression, decreasing the nitrogen metabolic enzymes activites except NR. The above results were consistent with the previous hypothesis. Noteworthily, GDH showed an increasing trend under the same conditions. We speculated that Masson pine mainly synthesized glutamic acid through the GDH pathway when $\mathrm{CO}_{2}$ concentration increased (Figure 3). Additional studies on this phenomenon are needed. As the first report on the response of nitrogen metabolism to $\mathrm{CO}_{2}$ stress in Masson pine needles, this study provides a valuable basis for further research in this area. 


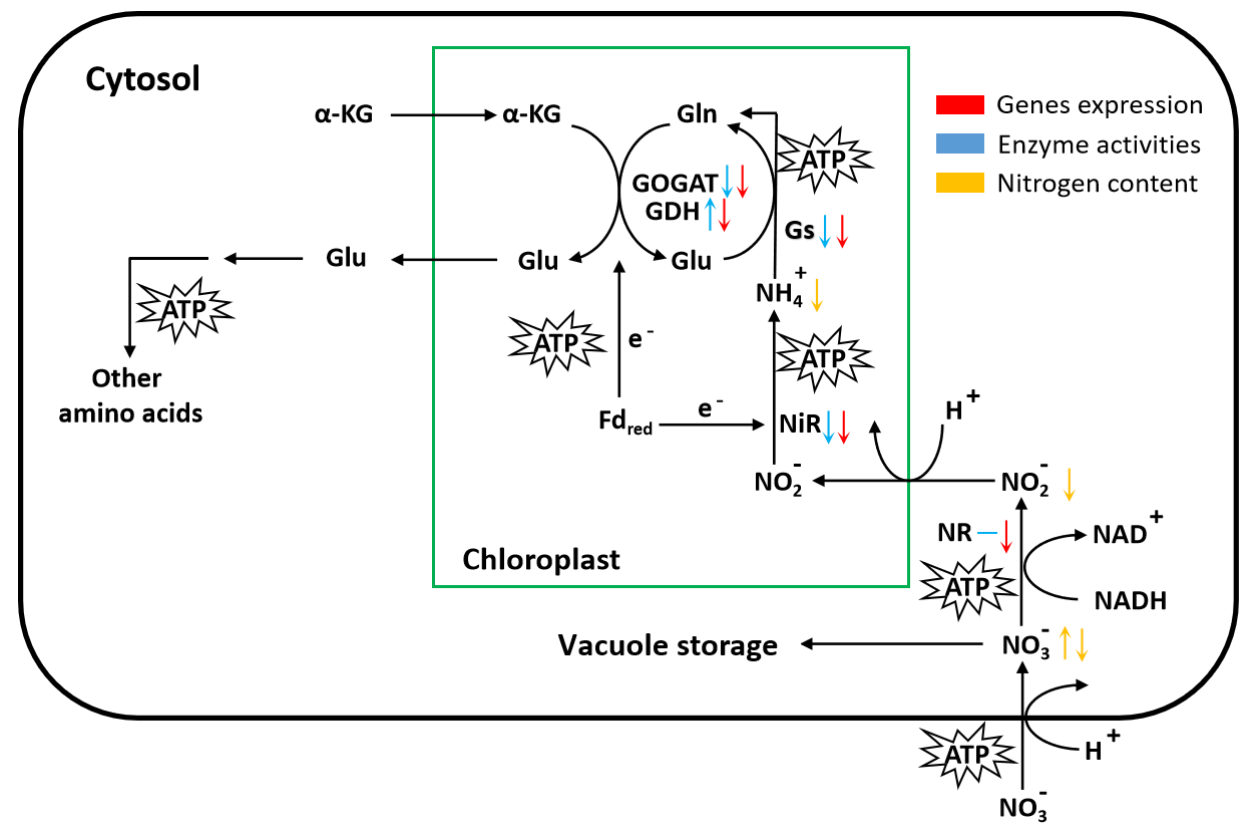

Figure 3. Influence of high $\mathrm{CO}_{2}$ concentration on nitrogen metabolism regulation in Masson pine needles. Biosynthesis pathways according to Taiz [56]. The green and black rectangles represent the chloroplast and cytosol, respectively. The gene expression, enzyme activities and the content of different nitrogen forms are shown in red, blue and orange, respectively. Up- and downward-facing arrows indicate up- and downregulated expression, respectively. The blue line in NR indicates that there is no difference in the enzyme activity expression of NR, and the specific data are shown in Figure 1B. $\alpha-K G$, $\alpha$-Ketoglutaric acid; Fdred, Reduced ferredoxin.

Author Contributions: Conceptualization, F.W. and K.J.; software, X.H. and J.L.; investigation, W.F., N.L. and X.S.; resources, B.Z. and N.L.; writing—original draft preparation, F.W. and X.S.; writing-review and editing, F.W. and K.J.; visualization, F.W., J.L. All authors approved the final draft. All authors have read and agreed to the published version of the manuscript.

Funding: The research was financially supported by the National Key R\&D Program of China (2017YFD0600304) and the Priority Academic Program Development of Jiangsu Higher Education Institutions (PAPD).

Conflicts of Interest: The authors declare that they have no competing interests.

\section{References}

1. Gomez-Casanovas, N.; Blanc-Betes, E.; Gonzalez-Meler, M.; Azcon-Bieto, J. Changes in Respiratory Mitochondrial Machinery and Cytochrome and Alternative Pathway Activities in Response to Energy Demand Underlie the Acclimation of Respiration to Elevated $\mathrm{CO}_{2}$ in the Invasive Opuntia ficus-indica1 [OA]. Plant Physiol. 2007, 145, 49-61. [CrossRef] [PubMed]

2. GCP. Carbon Budget. Available online: http://www.globalcarbonproject.org/carbonbudget (accessed on 13 March 2020).

3. Ehleringer, J.R.; Schulze, E.D. Ecosystem Physiology Responses to Global Change; Cambridge University Press: Cambridge, UK; London, UK, 1999; pp. 14-16.

4. Wang, W.M.; Wang, C.; Li, C.J.; Lin, W.H. Effects of elevated atmospheric $\mathrm{CO}_{2}$ concentrations on growth of plants. Acta Bot. Boreal. Occident. Sin. 2000, 20, 676-683.

5. Thilakarathne, C.L.; Tausz-Posch, S.; Cane, K.; Norton, R.M.; Tausz, M.; Seneweera, S. Intraspecific variation in growth and yield response to elevated $\mathrm{CO}_{2}$ in wheat depends on the differences of leaf mass per unit area. Funct. Plant Boil. 2013, 40, 185-194. [CrossRef]

6. Wu, Q.; Zhang, C.; Yu, Z.; Zhang, J.; Zhu, C.; Zhao, Z.; Xiong, J.; Chen, J. Effects of elevated $\mathrm{CO}_{2}$ and nitrogen addition on organic carbon and aggregates in soil planted with different rice cultivars. Plant Soil 2018, 432, 245-258. [CrossRef] 
7. Kleinhofs, A.; Warner, R.L. Advances in Nitrate Assimilation; Elsevier BV: Amsterdam, The Netherlands, 1990; pp. 89-120.

8. Lea, P.J.; Robinson, S.A.; Stewart, G.R. The Enzymology and Metabolism of Glutamine, Glutamate and Asparagine Intermediary Nitrogen Metabolism the Biochemistry of Plants; Academic Press: New York, NY, USA, 2012; pp. $44-51$.

9. Men, Z.H.; Li, S.X. Effect of $\mathrm{CO}_{2}$ concentration on nitrogen metabolism of winter wheat. Zhongguo Nongye Kexиe 2005, 38, 320-326.

10. $\mathrm{Xu}, \mathrm{Y} . \mathrm{B}$. Effect of $\mathrm{CO}_{2}$ Enrichment on Plant Growth and Nitrogen Use of Winter Wheat. Master's Thesis, Northwest Agriculture and Forestry University, Xianyang, China, 2012.

11. Bassirirad, H.; Thomas, R.B.; Reynolds, J.F. Differential responses of root uptake kinetics of $\mathrm{NH}_{4}{ }^{+}$and $\mathrm{NO}_{3}{ }^{-}$ to enriched atmospheric $\mathrm{CO}_{2}$ concentration in field-grown loblolly pine. Plant Cell Environ. 1996, 16, 957-962. [CrossRef]

12. Su, W.L. Effects of Elevation $\mathrm{CO}_{2}$ on Nitrogen Uptake Characteristic and Growth of Larix Gmelinii and Pinus Sylvestris var. Mongolica. Master's Thesis, Northeast Forestry University, Harbin, China, 2008.

13. Johnson, D.; Cheng, W.; Ball, J. Effects of $\mathrm{CO}_{2}$ and $\mathrm{N}$ fertilization on decomposition and $\mathrm{N}$ immobilization in ponderosa pine litter. Plant Soil 2000, 224, 115-122. [CrossRef]

14. Pang, J.; Zhu, J.G.; Liu, G. Effects of free-air $\mathrm{CO}_{2}$ enrichment (FACE) on concentrations of various $\mathrm{N}$ forms in rice tissues. J. Agro-Environ. Sci. 2005, 24, 833-837.

15. Johansson, E.M.; Fransson, P.M.A.; Finlay, R.D.; Van Hees, P. Quantitative analysis of soluble exudates produced by ectomycorrhizal roots as a response to ambient and elevated $\mathrm{CO}_{2}$. Soil Boil. Biochem. 2009, 41, 1111-1116. [CrossRef]

16. Chen, F.J.; Ge, F.; Liu, X.H. Responses of cotton to elevated $\mathrm{CO}_{2}$ and the effects on cotton aphid occurrences. Acta Ecol. Sin. 2004, 24, 991-996.

17. Han, X. Effects of Free Air $\mathrm{CO}_{2}$ Enrichment on Wheat Growth and Yield: The Physiological Basis. Ph.D. Thesis, Chinese Academy of Agricultural Sciences, Beijing, China, 2012.

18. Wang, X.J. Effect of $\mathrm{CO}_{2}$ Enrichment on Growth, Root Uptake Characteristics and Efficiency in Oilseed Rape; Hunan Agricultural University: Changsha, China, 2012.

19. Li, Z.X. Effects of Elevated $\mathrm{CO}_{2}$ and Heat Stress on Growth and Development of Tea Plant. Master's Thesis, Chinese Academy of Agricultural Sciences, Beijing, China, 2016.

20. Yang, C.; Tan, T.; Zhang, L.; Yu, J.L.; Liao, Q.; Zhang, Z.H.; Liu, Q.; Rong, X.M.; Song, H.X.; Guan, C.Y. Effects of high $\mathrm{CO}_{2}$ concentration in atmosphere on nitrogen assimilation and plant growth of Oilseeds Rape (Brassica napus L.). Ecol. Environ. Sci. 2013, 22, 1688-1694.

21. Hocking, P.; Meyer, C. Effects of $\mathrm{CO}_{2}$ Enrichment and Nitrogen Stress on Growth, and Partitioning of Dry Matter and Nitrogen in Wheat and Maize. Funct. Plant Boil. 1991, 18, 339-356. [CrossRef]

22. Bauer, G.; Berntson, G.M. Ammonium and nitrate acquisition by plants in response to elevated $\mathrm{CO}_{2}$ concentration: The roles of root physiology and architecture. Tree Physiol. 2001, 21, 137-144. [CrossRef] [PubMed]

23. Constable, J.V.H.; BassiriRad, H.; Lussenhop, J.; Zerihun, A. Influence of elevated $\mathrm{CO}_{2}$ and mycorrhizae on nitrogen acquisition: Contrasting responses in Pinus taeda and Liquidambar styraciflua. Tree Physiol. 2001, 21, 83-91. [CrossRef] [PubMed]

24. Ni, Z.; Ye, Y.; Bai, T.; Xu, M.; Xu, L.-A. Complete Chloroplast Genome of Pinus massoniana (Pinaceae): Gene Rearrangements, Loss of ndh Genes, and Short Inverted Repeats Contraction, Expansion. Molecules 2017, 22, 1528. [CrossRef]

25. Ni, Z.; Zhou, P.; Xu, M.; Xu, L.-A. Development and characterization of chloroplast microsatellite markers for Pinus massoniana and their application in Pinus (Pinaceae) species. J. Genet. 2018, 97, 53-59. [CrossRef]

26. Zhang, Y.; Zhou, Z.; Yang, Q. Nitrogen (N) Deposition Impacts Seedling Growth of Pinus massoniana via N:P Ratio Effects and the Modulation of Adaptive Responses to Low P (Phosphorus). PLoS ONE 2013, 8, e79229. [CrossRef]

27. Guan, L.L.; Wen, D. More nitrogen partition in structural proteins and decreased photosynthetic nitrogen-use efficiency of Pinus massoniana under in situ polluted stress. J. Plant Res. 2011, 124, 663-673. [CrossRef]

28. Ni, C.; Wang, D.; Tao, Y. Variable weighted convolutional neural network for the nitrogen content quantization of Masson pine seedling leaves with near-infrared spectroscopy. Spectrochim. Acta Part A: Mol. Biomol. Spectrosc. 2019, 209, 32-39. [CrossRef] 
29. Treder, K.; Wanic, M.; Jastrzebska, M. The Influence of interaction between spring wheat and spring barley on accumulation of nitrogen, phosphorus and potassium in plants. Ann. UMCS, Agric. 2009, 64, 94-106. [CrossRef]

30. Zhang, Z.L.; Li, X.F. Experimental Guidance of Plant Physiology; Higher Education Press: Beijing, China, 2016; pp. 36-48.

31. Zhu, P.; Ma, Y.; Zhu, L.; Chen, Y.; Li, R.; Ji, K.S.; Ji, K.S. Selection of Suitable Reference Genes in Pinus massoniana Lamb. Under Different Abiotic Stresses for qPCR Normalization. Forests 2019, 10, 632. [CrossRef]

32. XCMS. Meta XCMS. Available online: http://metlin.scripps.edu/xcms (accessed on 5 January 2020).

33. Li, M.; Li, Y.; Zhang, W.; Li, S.; Gao, Y.; Ai, X.; Zhang, D.; Liu, B.; Li, Q. Metabolomics analysis reveals that elevated atmospheric $\mathrm{CO}_{2}$ alleviates drought stress in cucumber seedling leaves. Anal. Biochem. 2018, 559, 71-85. [CrossRef] [PubMed]

34. Andersen, K.; Mayor, J.R.; Turner, B.L. Plasticity in nitrogen uptake among plant species with contrasting nutrient acquisition strategies in a tropical forest. Ecology 2017, 98, 1388-1398. [CrossRef] [PubMed]

35. Marschner, H. Functions of mineral nurtients: Macronutrients. In The Mineral Nutrition of Higher Plants, 2nd ed.; Marschner, P., Ed.; Academic Press: New York, NY, USA, 1995; pp. 229-255.

36. Zhao, X. Effect of Elevated Root-Zone $\mathrm{CO}_{2}$ Concentration on Melon Seeding Nitrogen Absorption, Metabolism and Transport in Root. Master's Thesis, Shengyang Agricultural University, Shenyang, China, 2012.

37. Thornton, B.; Robinson, D. Uptake and assimilation of nitrogen from solutions containing multiple $\mathrm{N}$ sources. Plant Cell Environ. 2005, 28, 813-821. [CrossRef]

38. Ma, Q.; Wang, J.; Sun, Y.; Yang, X.; Ma, J.; Li, T.; Wu, L. Elevated $\mathrm{CO}_{2}$ levels enhance the uptake and metabolism of organic nitrogen. Physiol. Plant. 2017, 162, 467-478. [CrossRef]

39. Takatani, N.; Ito, T.; Kiba, T.; Mori, M.; Miyamoto, T.; Maeda, S.I.; Omata, T. Effects of high $\mathrm{CO}_{2}$ on growth and metabolism of Arabidopsis seedlings during growth with a constantly limited supply of nitrogen. Plant Cell Physiol. 2013, 55, 281-292. [CrossRef]

40. Teng, N.; Wang, J.; Chen, T.; Wu, X.; Wang, Y.; Lin, J. Elevated $\mathrm{CO}_{2}$ induces physiological, biochemical and structural changes in leaves of Arabidopsis thaliana. New Phytol. 2006, 172, 92-103. [CrossRef]

41. Weigel, H.J.; Manderscheid, R. Crop growth responses to free air $\mathrm{CO}_{2}$ enrichment and nitrogen fertilization: Rotating barley, ryegrass, sugar beet and wheat. Eur. J. Agron. 2012, 43, 97-107. [CrossRef]

42. Li, S.; Li, Y.; He, X.; Li, Q.; Liu, B.; Ai, X.; Zhang, D. Response of water balance and nitrogen assimilation in cucumber seedlings to $\mathrm{CO}_{2}$ enrichment and salt stress. Plant Physiol. Biochem. 2019, 139, 256-263. [CrossRef]

43. Vega-Mas, I.; Pérez-Delgado, C.M.; Marino, D.; Fuertes-Mendizábal, T.; González-Murua, C.; Marquez, A.J.; Betti, M.; Estavillo, J.M.; González-Moro, M.B. Elevated $\mathrm{CO}_{2}$ Induces Root Defensive Mechanisms in Tomato Plants When Dealing with Ammonium Toxicity. Plant Cell Physiol. 2017, 58, 2112-2125. [CrossRef]

44. Pan, R.C.; Wang, X.Q.; Li, N.H. Plant Physiology; Higher Education Press: Beijing, China, 2012; pp. $23-36$.

45. Torralbo, F.; Vicente, R.; Morcuende, R.; González-Murua, C.; Aranjuelo, I. C and N metabolism in barley leaves and peduncles modulates responsiveness to changing $\mathrm{CO}_{2}$. J. Exp. Bot. 2018, 70, 599-611. [CrossRef] [PubMed]

46. Pérez-López, U.; Robredo, A.; Miranda-Apodaca, J.; Lacuesta, M.; Muñoz-Rueda, A.; Petite, A.M. Carbon dioxide enrichment moderates salinity-induced effects on nitrogen acquisition and assimilation and their impact on growth in barley plants. Environ. Exp. Bot. 2013, 87, 148-158. [CrossRef]

47. Zaghdoud, C.; Carvajal, M.; Ferchichi, A.; Ballesta, M.M. Water balance and N-metabolism in broccoli (Brassica oleracea L. var. Italica) plants depending on nitrogen source under salt stress and elevated $\mathrm{CO}_{2}$. Sci. Total. Environ. 2016, 571, 763-771. [CrossRef] [PubMed]

48. Anabel, R.; Usue, P.; Jon, M.; Maite, L.; Amaia, M.; Alberto, M. Elevated $\mathrm{CO}_{2}$ reduces the drought effect on nitrogen metabolism in barley plants during drought and subsequent recovery. Environ. Exp. Bot. 2011, 13, 399-408.

49. Vicente, R.; Pérez, P.; Martinez-Carrasco, R.; Usadel, B.; Kostadinova, S.; Morcuende, R. Quantitative RT-PCR Platform to Measure Transcript Levels of $C$ and N Metabolism-Related Genes in Durum Wheat: Transcript Profiles in Elevated $\left[\mathrm{CO}_{2}\right]$ and High Temperature at Different Levels of N Supply. Plant Cell Physiol. 2015, 56, 1556-1573. [CrossRef] [PubMed]

50. Reyes, T.H.; Pompeiano, A.; Pompeiano, A.; Ciurli, A.; Lu, Y.; Guglielminetti, L.; Yamaguchi, J. Nitrate Reductase Modulation in Response to Changes in C/N Balance and Nitrogen Source in Arabidopsis. Plant Cell Physiol. 2018, 59, 1248-1254. [CrossRef] 
51. Koch, M.; Naumann, M.; Pawelzik, E.; Gransee, A.; Thiel, H. The Importance of Nutrient Management for Potato Production Part I: Plant Nutrition and Yield. Potato Res. 2019, 63, 97-119. [CrossRef]

52. Di Martino, C.; Fioretto, A.; Palmieri, D.; Torino, V.; Palumbo, G. Influence of Tomato Plant Mycorrhization on Nitrogen Metabolism, Growth and Fructification on P-Limited Soil. J. Plant Growth Regul. 2019, 38, 1183-1195. [CrossRef]

53. Batnini, M.; Lopez-Gomez, M.; Palma, F.; Haddoudi, I.; Kallala, N.; Zribi, K.; Mrabet, M.; Mhadhbi, H. Sinorhizobium spp inoculation alleviates the effect of Fusarium oxysporum on Medicago truncatula plants by increasing antioxidant capacity and sucrose accumulation. Appl. Soil Ecol. 2020, 150, 103458. [CrossRef]

54. Agtuca, B.J.; Stopka, S.; Tuleski, T.R.; Amaral, F.P.D.; Evans, S.; Liu, Y.; Xu, D.; Monteiro, R.A.; Koppenaal, D.W.; Tolic, L.P.; et al. In-Situ Metabolomic Analysis of Setaria viridis Roots Colonized by Beneficial Endophytic Bacteria. Mol. Plant-Microbe Interact. 2020, 33, 272-283. [CrossRef] [PubMed]

55. Moran-Duran, S.A.; Flynn, R.P.; Heerema, R.; VanLeeuwen, D. Leaf Net Photosynthesis, Leaf Greenness, and Shoot Lignin Content of Nonbearing Pecan Trees at Two Nitrogen and Nickel Application Rates. HortScience 2020, 55, 231-236. [CrossRef]

56. Taiz, L.; Zeiger, E. Plant Physiology; Sinauer Associates Press: North Carolina, NY, USA, 2006; pp. 57-78.

(C) 2020 by the authors. Licensee MDPI, Basel, Switzerland. This article is an open access article distributed under the terms and conditions of the Creative Commons Attribution (CC BY) license (http://creativecommons.org/licenses/by/4.0/). 